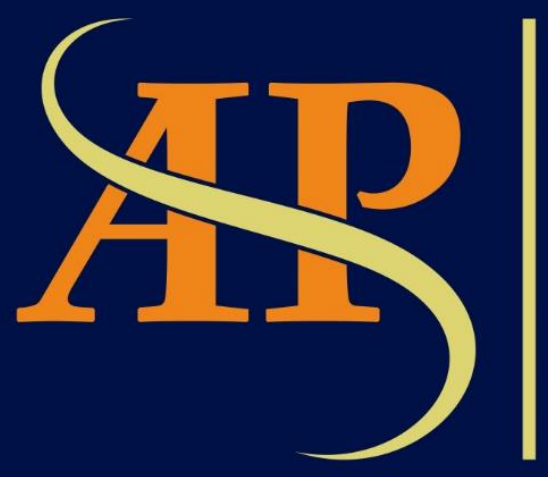

JURNAL

ASIA

PACIFIC

STUDIES

Journal of International Relations Study Program Faculty of Social and Political Sciences

Universitas Kristen Indonesia

Volume I | Number 2 | July - December 2017 


\title{
ACEH: EXPLORING THE AFTERMATH OF 2004 TSUNAMI FROM GENDER DIMENSIONS
}

\author{
Sorang Afril Srihayati Saragih \\ Gender and Peacebuilding, Department of Peace and Conflict Studies, \\ UN-mandated University for Peace, Ciudad Colón, San Jose, Costa Rica \\ sorang.saragih@gmail.com
}

\begin{abstract}
This paper aims to analyse the greatest gender-specific dimensions toward women in the case of the tsunami that hit Aceh Province in Indonesia in 2004. Using three gender dimensions, which are gender identity, gender structure and gender symbolism, it argues that this catastrophe was not gender-neutral and its impacts could be shown in four conditions of women; which were women's worsened insecurity and vulnerability, the feminization of poverty, the presence of "tsunami marriage", and the reinforced gendered roles. The concept of 'intersectionality' is useful to show the heterogeneous identity of women and how they were impacted by the disastrous event. It concludes that the 2004 tsunami brought many changes in the lives of both men and women in Aceh and worsened the inequalities between them.
\end{abstract}

Keywords: Aceh, women, tsunami, gender dimensions

\begin{abstract}
Abstrak
Tulisan ini bertujuan untuk menganalisis dimensi-dimensi terbesar yang spesifik-gender dalam kasus tsunami yang melanda Provinsi Aceh di Indonesia pada tahun 2004. Menggunakan tiga dimensi gender, yakni identitas gender, struktur gender dan simbolisme gender, tulisan ini menyatakan bahwa bencana ini tidaklah netral-gender dan dampaknya dapat ditunjukkan dalam empat kondisi perempuan; yaitu ketidakamanan dan kerentanan perempuan yang semakin memburuk, feminisasi kemiskinan, munculnya "pernikahan tsunami", dan peran-peran berbasis gender yang semakin menguat. Konsep 'interseksionalitas' berguna dalam memperlihatkan identitas heterogen perempuan dan bagaimana mereka terkena imbas dari peristiwa bencana tersebut. Tulisan ini berkesimpulan bahwa tsunami di tahun 2004 itu membawa banyak perubahan dalam hidup laki-laki dan perempuan di Aceh, serta memperburuk ketimpangan di antara mereka.
\end{abstract}

Kata Kunci: Aceh, perempuan, tsunami, dimensi gender 


\section{Tsunami in Aceh and Its Gendered Victims}

Aceh is a province of Indonesia, located at the northern tip of Sumatra Island. This province has a strong patriarchal system and the leaders also used religious influence to maintain this structure because almost all people in this province were Muslims (Leo-Koo 2012). On December 26, 2004, a 30-meter tsunami hit Aceh, only less than half an hour after a magnitude 9.2 quake hit its coast at $8 \mathrm{a} . \mathrm{m}$. local time for around nine minutes. The tsunami also attacked 13 other countries, but Aceh was the most affected area, causing more than 150,000 people dead in this province alone; particularly from the coastal areas facing the Indian Ocean (Bangka Pos 2016).

Prior to 2004 tsunami, Aceh had been under a protracted conflict between GAM (Free Aceh Movement), an Acehnese separatist group, and the government of Indonesia since 1976. Several peace talks had been initiated before the tsunami occurred, but it always failed. The last peace negotiation before the tsunami disaster managed to produce a peace agreement called the Cessation of Hostilities Agreement (CoHA) in December 2002, but it failed on May 18, 2003, and the government of Indonesia imposed martial law in Aceh on the next day until the tsunami disaster came (Schaffer 2011). The tsunami stopped the conflict because it destroyed most of the resources of GAM. It further led to the successful peace negotiation because GAM no longer had any power to fight against the government.

The tsunami disaster was not gender-neutral because it killed more women than men. It was reported that more than $70 \%$ of the dead victims in Aceh were women living in the coastal areas (UNDP 2013; Ariyabandu 2009; Felten-Biermann 2006; UNFPA, Oxfam Great Britain, and Women Studies Centre of Ar Ranirry State Institute for Islamic Studies 2005). Thus, the gender ratio in the affected areas was shifted because women were much fewer than men after the tsunami disaster.

There were several factors explaining the death of these women victims. Firstly, the tsunami happened in the early Sunday morning, so most women did not work outside their homes. They were at home with their family while many men went to sea for fishing as it was one of the main occupations in the coastal areas in Aceh. These men were still alive after the tsunami came because they did not experience the same brute force as the people were on the coast (UNFPA, Oxfam Great Britain, and Women Studies Centre of Ar Ranirry State Institute for Islamic Studies 2005). Secondly, women could not move quickly to rescue because they also had to save their children and older relatives who were with them. Because of this additional burden, they moved more slowly and became exhausted more quickly than the men. Thirdly, women were rarely taught swimming or climbing as these were considered men's activities. Thus, they could not save themselves from the water or climb a tree to avoid the wave attack. Lastly, women's clothing style also gave a disadvantage to them. Their long traditional skirt complicated their efforts to climb a tree (Muktakhamah 2013).

\subsection{Research Question}

According to the description above, the important question to ask, then, is how does the tsunami 2004 affect women's lives in Aceh afterward?

\subsection{Aims of the Research}

The aim of this paper is to describe the impacts received by women in Aceh after tsunami 2004. The second goal of this writing is to examine the different experiences of discrimination 
faced by women. It is their heterogeneous roles and identities which produce intersecting oppressions toward women in post-tsunami 2004 Aceh.

\subsection{Benefits of the Research}

Analysing the gendered impacts of a catastrophe will be useful for understanding the overall impact of the disaster. This research will also be useful for science in the way of exploring women's experience as a source of knowledge. For public stakeholders, this research will be useful in encouraging more equitable post-disaster policies.

\section{Literature Review}

There are some intriguing scholarships exploring the ways in which relations of power and social inequality manifested in the disastrous events. Among them, Madhavi Malalgoda Ariyabandu (2009) was one among the firsts theorizing gendered power relations in a disaster. Generally, gendered identities, roles, and responsibilities are prevalent within the social and community organization. They, Ariyabandu said, lead to substantial differences in how men and women of all age groups experience and deal with disasters before, during and in the aftermath (Ariyabandu 2009, 5-6). According to her, disasters are windows that showcase the prevailing gender-based inequalities in society. As a researcher and practitioner, she discussed the gender issues with the survival and recovery of a disaster. She concluded that insensitive gender actions in the disaster cycle in effect force women into situations of distress, humiliation, increased the risk of being victims of violence and reduced access to available opportunities and options to men. Moreover, she saw that inaccurate gender assumptions and insensitivity to women's issues and gender perspective in development planning and disaster risk reduction will only make the interventions fail to reach both the development and disaster reduction goals.

Meanwhile, the invisible gendered power relations in sciences was first investigated by Sandra Harding (1986). The products of thought bear the mark of their collective and individual creators, mainly of modern Western culture. The culture's favored beliefs reflected in the way sciences understand the world as it is. Part of the culture is gender differences. According to Harding, it is the most ancient, most universal, and most powerful origin of many morally valued conceptualizations of everything else in the world. For example, cultures assign a gender to such non-human entities as hurricanes and mountains, ships and nations, as well as the other social and natural worlds organization in terms of gender meanings; within which historically specific racial, class, and cultural institutions and meanings have been constructed (Harding 1986, 17). Thus, Harding believes that gender is an analytical category within which humans think about and organize their social activity rather than as a natural consequence of sex difference, or even merely as a social variable assigned to individual people in different ways from culture to culture. Gender meanings have suffused human's belief systems, institutions, and even such apparently gender-free phenomena-including science.

In her article, Harding (1986) highlighted three dimensions of gendered social life reproduction system to better discern the effects of these cultural markings in science, which are identity, structure, and symbolism. As an ordering principle by which every society is organized, this means that the 'gender system' can be distinguished into three analytical categories: the "pivotal way in which humans identify themselves as persons (individual gender or gender identity), organize social relations (gender structure), and symbolize meaningful natural and social events and processes (gender symbolism)" (Harding 1986, 18). These three dimensions of gender are related to each other within any culture. Harding also recognized that the gendered social stratification is, in fact, intersecting with racial and class stratification. 
Due to women's heterogeneity, some other research coined the term 'intersectionality' by considering the ways in which gender intersects with other categories of social structure, such as race, ethnicity, class, and age (Crenshaw 1989; Collins 2000). During disasters, those diverse women's experiences mirror the production or reproduction of social injustice. Rachel E. Luft (2016) has developed the concept of 'intersectionality' to make a gender- and raceconscious framework, which exposed the way in which structural sexism and racism, came together to produce the Hurricane Katrina in 2005 and the social justice response to it. Following Naomi Klein's "disaster capitalism", Luft named the framework as the "racialized disaster patriarchy" as it refers to an intersectional model that describes gender, racial, and economic practices that converge before, during, and after a disaster to produce intersectional injustice (Luft 2016, 7).

\section{Research Method}

The research used a qualitative approach to understand how tsunami 2004 affects women's lives in Aceh afterward. Literature study became the method to gather the required data. The data used here coming from secondary sources, which are some research and policy reports, news, and journal articles concerning women in post-tsunami Aceh and the social context of the catastrophe. The gender dimensions of identity, structure, and symbolism were also used to analyze the impacts of tsunami towards women's condition in Aceh. To address the heterogeneous identity of women in Aceh, the concept of 'intersectionality' is used to show how they were impacted by the disastrous event.

\section{Results and Discussions}

\subsection{The Social Context of Aceh in 2004}

The coast of Aceh was directly affected by the tsunami in 2004. While the affected areas are predominantly rural, there are several urban areas, including the provincial capital Banda Aceh. Rural population densities are relatively high in the lowlands that skirt the coast. The lowland population is predominantly Acehnese but also includes populations descended from Javanese, Minangkabau and Chinese immigrants (Gray et al. 2009, 6).

Based on UNDP Press Release, Aceh was a province of just over four million people with 221,000 residents in the capital Banda Aceh before the tsunami ("Aceh: Before the Tsunami" 2005). According to the press release, Aceh was already a province with urgent development needs without the tsunami. The main sources of livelihoods in Aceh have traditionally been agriculture, animal husbandry, fishing, and trade. Its main agricultural product is rice, but many families also raise livestock. Whereas almost 9 per cent of all villages in Aceh are fishing villages and fishing is predominant in coastal communities. The large population of Aceh is an important asset for development (UNFPA, Oxfam Great Britain, and Women Studies Centre of Ar Ranirry State Institute for Islamic Studies 2005, 5-6). However, there were major problems with health access, in which $38 \%$ of the residents had no access to health facilities in 2003, and poverty in the society; in which $48 \%$ of them had no access to clean water in the same year, a third of all households had no access to sanitation, $35.2 \%$ of children under five were recorded as being under nourished also in 2003, and there were also particular problems in areas affected by the conflict with GAM ("Aceh: Before the Tsunami" 2005). The secessionist struggle had brought an issue of internally displaced persons prior to the tsunami. 
The population is 99\% Muslim, and Sharia law is applied since 2002 during the leadership of Governor Abdullah Puteh. In the Aceh Province, there were some issues when the local government wanted to implement Sharia law. It is because the implementation of the law will influence non-Muslim residents' lives in Aceh Province area (Safrilsyah 2012). Acehnese women are caught between the social institutions of religion, GAM, and the national government. Religious leaders and GAM tend to want women to conform to their interpretation of Islam; for example, in the obligation on women to wear headscarves. It was reflected by Safrilsyah, whose research found that $40 \%$ of Non-Muslim respondents were worried about the implementation of the law. They were not comfortable with the unannounced examination of Muslim clothes and the scarf (Safrilsyah 2012, 548).

It was understandable that many cultural practices and traditions in Aceh have particular connections to Islam. The religious belief has been already an inseparable part of the Acehnese even before the formalization of the Sharia law. Aceh was the first region in Indonesia to be influenced by Islam, that is in the period of Sultan Ali Mughayatsyah of the Aceh Darussalam Kingdom in the 16th century (UNFPA, Oxfam Great Britain, and Women Studies Centre of Ar Ranirry State Institute for Islamic Studies 2005, 5).

The Acehnese also has some strong traditions considered to have existed in Aceh for centuries. These traditions support dominant views of Acehnese identity, particularly in regards to men and women's social roles. Aceh, along with the Minangkabau, is a matrifocal society, in which women have dominant roles, especially within a family. Srimulyani said that the practice and meaning of matrifocality differ from 'female-headed household'. The familial setting is quite different in Aceh. The people rarely identified heads of a household, as sometimes there are extended families live in the same house. Men will move to the households and villages of their wives after they get married. They have limitations in terms of power and access for family decision making because they are seen as a 'guest' in the family. They usually leave their village for merantau or generate income for the family away from home. As a result, the children never get close with their father; a mother or a wife is the one responsible for any family affairs at home. In this setting, elderly women used to have a 'relative' power and social bargain (Srimulyani 2015, 315). However, due to the matrifocal tradition which centers on the residence of a wife's mother's family, the social interaction of husband and wife is already arranged. Husband is not supposed to stay at home with his wife and children, but mostly with his other men of the village in the meunasah or surau, the small mosque for prayer (Srimulyani 2015, 316). Even though many women become heads of households nowadays, the tradition contributes to the low female participation in the political process in Aceh.

\subsection{Women's Worsened Insecurity and Vulnerability in Post-tsunami Aceh}

The death of many women during the tsunami disaster led to a logical consequence that there were fewer women survivors in the evacuation camps. These women became vulnerable due to the lack of privacy because there was no separation between female and male latrines and those were built with semi-permanent materials and improper conditions, such as tarpaulin, plastic door, or door without lock (UNFPA, Oxfam Great Britain, and Women Studies Centre of Ar Ranirry State Institute for Islamic Studies 2005). Even worse, there were some camps that did not have a latrine or have latrine with no water. Thus, the people there had to take a bath to the beach early in the morning, such as experienced in the camps in Lampaseh Kota, Keude Panteraja, and Alue Dayah (UNFPA, Oxfam Great Britain, and Women Studies Centre of Ar Ranirry State Institute for Islamic Studies 2005). This put women in a vulnerable situation because it was not safe to go there without any male friends and if the friends accompanied them, they would not be comfortable in taking a bath there. Consequently, a big number of 
sexual harassment was reported in many camps (Felten-Biermann 2006). Because of these difficult situations, many women had a problem with their reproductive health after they decided to not take a bath for weeks (Ariyabandu 2009).

Among the women survivors, pregnant women became one of the most vulnerable groups due to the lack of medical staffs to give a special attention to them and the asymmetric power they had in the family (UNFPA, Oxfam Great Britain, and Women Studies Centre of Ar Ranirry State Institute for Islamic Studies 2005). The medical staffs did not visit the camps daily, thus, pregnant women had to look for midwives or traditional birth attendants when they wanted to deliver their babies. If a problem related to the pregnancy occurred, the women had no rights to make any decision, because it depended on the men with the support from their family (UNFPA, Oxfam Great Britain, and Women Studies Centre of Ar Ranirry State Institute for Islamic Studies 2005). The situations, combined with the lack of access to water, led to the cases of miscarriages, premature births, and women or babies dying during the delivery. However, the number of actual cases was unknown although there were some reports on it.

Women survivors also became more prone to sexual violence. The actual number of this violence was never known because it was considered as a sensitive issue in Aceh, the victims would face discrimination and prejudice in the community. Moreover, the authorities would often disregard their reports. A local NGO reported that some senior council members of evacuation camps turned down the reports from raped women to prevent further investigation in the camps (Felten-Biermann 2006). Moreover, there was no any official or unofficial mechanism provided to report the occurrence of sexual violence. There was no any guideline either for medical staffs assigned in the affected areas to respond the victims of sexual violence (Felten-Biermann 2006). Despite the situation, Komnas Perempuan, The Indonesian National Commission on Violence against Women, managed to discover more than 40 cases of violence against women in the evacuation camps, consisted of more than 30 cases rape committed by victims' family members and more than seven cases committed by strangers (Felten-Biermann 2006). In some cases, women also experienced sexual exploitation from other men in exchange for food, money, or protection from other men (UNFPA, Oxfam Great Britain, and Women Studies Centre of Ar Ranirry State Institute for Islamic Studies 2005). This violence was also hidden because of the fear of stereotype and discrimination from the community.

In line with that, there were also several reports of the domestic violence against women. This type of violence also did not have an actual number because it was regarded as a private issue, but many people acknowledged that they witnessed this violence in their evacuation camps or communities (UNFPA, Oxfam Great Britain, and Women Studies Centre of Ar Ranirry State Institute for Islamic Studies 2005). It was argued that the lack of psychological support for survivors, especially for the men, contributed to this problem. Different from women who tended to be able to help their own selves by sharing their feelings with other women, men tended to hide their feelings and showed those through their aggressive behaviour instead, particularly against their wives and children (Felten-Biermann 2006; UNFPA, Oxfam Great Britain, and Women Studies Centre of Ar Ranirry State Institute for Islamic Studies 2005). Children, especially the daughters, also experienced violence, which is forced marriage. This violence would be further explained in the section of the presence of "tsunami marriage".

\subsection{The Feminization of Poverty}

The tsunami disaster led to the increasing rate of poverty in Aceh with women as the majority of the victims. In Aceh, a woman survivor usually had a right to own her deceased husband's or father's properties, but the extended family had a power to decide her inheritance. The woman usually received less or even did not receive anything if the family or community 
leaders decided so (UNFPA, Oxfam Great Britain, and Women Studies Centre of Ar Ranirry State Institute for Islamic Studies 2005). She was more vulnerable to poverty when her husband died. It was more difficult for her to access aid because it was usually distributed only to the male household (Muktakhamah 2013). This was in contrast with the case of a man with a deceased wife or father because he usually received the properties automatically or got the bigger share. Also, he did not find any difficulties to access the aid because he was automatically considered as the recipients.

The gendered division of ownership also made women more vulnerable to personal poverty (UNFPA, Oxfam Great Britain, and Women Studies Centre of Ar Ranirry State Institute for Islamic Studies 2005). Women usually owned mobile properties, such as jewelry, while men usually owned more fixed ones, such as land or house. Due to the difficult situation, women usually had to sell their properties first because it was easier to do than men's properties. This put women in a risky condition in the future because of the bigger insecurity they had after they sold the properties.

Moreover, the gendered division of labour was still preserved in the early post-tsunami period. When ILO (International Labor Organization) sponsored employment for women, they usually chose work related to care-taking or handicraft, such as cooking, sewing, nursing, weaving, and teaching (Eye on Aceh and Aidwatch 2006). On one side, these choices were understandable because those were the only skills that they had. However, on the other said, it perpetuated the gendered division of labour between men and women because most of the available livelihood assistance for women were only these works. Moreover, it was more difficult for women to transform their lives if they only relied on these micro-finance activities and low-paying jobs.

In their joint research, UNFPA, Oxfam International, and Women Studies Center also discovered that the bad administration of replacing the lost documents contributed to the feminization of poverty (UNFPA, Oxfam Great Britain, and Women Studies Centre of Ar Ranirry State Institute for Islamic Studies 2005). Accessing formal work required the presence of key documents, such as ID card and diploma and these documents were lost in the tsunami. Many poor women decided not to renew these documents because they did not have money to pay the expensive fee. Besides, they did not have much free time to follow the complicated process due to their responsibility to manage the household and to work hard for their daily survival. The absence of these documents closed their opportunity to apply for work in the formal sector. Consequently, some of the women were reported to become a hidden prostitute so that they could survive (UNFPA, Oxfam Great Britain, and Women Studies Centre of Ar Ranirry State Institute for Islamic Studies 2005).

\subsection{The Presence of "Tsunami Marriage"}

Not long after the tsunami disaster, the number of marriage was increasing because they saw marriage as a coping mechanism. Thus, it was called "tsunami marriage" (Felten-Biermann 2006, 83). The marriage was usually held individually, but there were times when there was an exception to this common practice by holding a mass marriage to reduce the cost. As a local newspaper reported, a mass marriage happened in an evacuation camp in Banda Aceh in June 2005 (UNFPA, Oxfam Great Britain, and Women Studies Centre of Ar Ranirry State Institute for Islamic Studies 2005).

Besides the phenomenon of mass marriages, there had been two other major changes in the common traditional rules on marriage in Aceh after the tsunami disaster. The marriage was no longer happened only between people from the same community due to the lack of women survivors in the community. In many cases, the gender ratio was so big that made impossible 
for them to get married if they kept maintaining the tradition. For example, in the camp "Pengungsi Leupung", there were more than 150 male survivors with less than seven female survivors (Felten-Biermann 2006; UNFPA, Oxfam Great Britain, and Women Studies Centre of Ar Ranirry State Institute for Islamic Studies 2005). Because of this situation, many men had to marry women from other communities. This also opened a possibility for marriage between people from different social classes. Before the tsunami disaster, people from high social class, such as the member of royal family (Teuku for men and Cut for women) and of the perceived descendants of Prophet Muhammad (Sayyid for men and Syarifah for women) would only get married to people its own group (UNFPA, Oxfam Great Britain, and Women Studies Centre of Ar Ranirry State Institute for Islamic Studies 2005). After the tsunami disaster, some of them also got married to the ordinary people.

Many people in Aceh got married or remarried with different reasons during that time. Some people decided to get married to have an emotional support from the new partner or to replace their children who were missing or dead in the tsunami disaster (Felten-Biermann 2006; UNFPA, Oxfam Great Britain, and Women Studies Centre of Ar Ranirry State Institute for Islamic Studies 2005). Some men chose to remarry so that there would be someone to take care of the family, particularly to do the domestic chores and to look after their children. They preferred getting remarried to replacing their wife's role in the family, as well said by a man during a focus group discussion in Aceh in April 2005:

\footnotetext{
"[We] are concerned about our children, what their future will be like, who will guide them... There is nobody to share our thoughts... So, to overcome this problem, we think that the best solution is to get married" (UNFPA, Oxfam Great Britain, and Women Studies Centre of Ar Ranirry State Institute for Islamic Studies 2005, 27).
}

Other people chose to get marry or remarry to maintain their familial ties so that the inheritance would not go to the new outsider. This practice was also believed to help the children better adjust to the new change in the family because a connection between them and the new wife had already existed. The rest decided to do that to have a financial security. For this reason, the marriage usually occurred between a rich widow with a young man and a rich widower with a young woman (UNFPA, Oxfam Great Britain, and Women Studies Centre of Ar Ranirry State Institute for Islamic Studies 2005). For a rich widow, the remarriage would save her name because being a widow was usually attributed to some negative stereotypes. However, she had to wait for his proposal although she was older than him, as a woman could not initiate a marriage in Aceh. More than that, a widow faced a special difficulty in getting remarried from the Islamic law. Under this law, she had to wait for four months and 10 days after the death of her husband before she could remarry again to ensure that she was not pregnant from her deceased husband when she got married. As most people in Aceh are Muslim, they usually practised this tradition and knowing the father of a child would determine inheritance the child would receive, the marriage guardian for a girl, and whom the child would be allowed to marry with (UNFPA, Oxfam Great Britain, and Women Studies Centre of Ar Ranirry State Institute for Islamic Studies 2005). In contrast, a widower did not have a waiting period to get remarried. For the young man, he got two benefits by marrying a widow. Firstly, he did not need to pay a high dowry because the dowry of a widow was less than a single woman. Secondly, the marriage would save his future as he did not need to work hard to make a living.

Similarly, a young woman would usually get married to a rich widower to save her and her own family's future because the widower will pay a high dowry for the marriage. Some rich widowers even were willing to give a house and a land to the woman's parents for the marriage. However, this led to the violations of women's and girls' rights through the practice of forced 
marriage and child marriage. Komnas Perempuan discovered that four girls aged 14-20 years old were forced to get married to widowers (Felten-Biermann 2006). Since this was considered as a sensitive topic in Aceh, there might have been more similar cases than this commission had found.

\subsection{The Reinforced Gendered Roles}

The tsunami disaster caused the increased number of widows and widowers. Widows with surviving children usually became single parents and replaced the deceased husbands' role as the main breadwinner for their family. Differently, the widowers who still have surviving children usually requested their female relatives to look after the children and to do domestic work, either by paying them or asking it for free. Asking help from their female relatives was the only choice because other women who did not have any familial ties were not willing to do that because they were afraid that the community would think that they had an affair with the widowers (UNFPA, Oxfam Great Britain, and Women Studies Centre of Ar Ranirry State Institute for Islamic Studies 2005). For widowers who had a grown-up daughter, they would ask her to replace her mother's role in the family, pushing her to manage the household earlier than she should be. Sometimes, the widowers even forced her to replace her mother sexually, as Komnas Perempuan had also found in its research in Aceh (UNFPA, Oxfam Great Britain, and Women Studies Centre of Ar Ranirry State Institute for Islamic Studies 2005).

The reinforced stereotype between men and women after the tsunami disaster in Aceh was not only on the division of labour but also on the division of space related to decision making. Women were subordinated in the decision-making process in the community. Before the tsunami disaster, they never participated in making a public decision in Aceh. As reported by Eye on Aceh and Aidwatch (2006), it was an exclusive role of men. When a community needed to decide something on an issue requested by the local government, the village head would always invite all men in the village, but not the women nor female-headed households. They would only know the decision from their male relatives or through village network. For internal issues, the meeting would be designed to exclude women by holding it in a local coffee shop (warung kopi), a common place in Aceh for male gathering, or after an evening prayer, a prayer only consisting of men. During the recovery period in Aceh, many organisations had tried to involve women in the decision-making process by requiring female participants in consultative meetings. The women did come but they only became passive observers because male participants often did not engage them in the discussion (Eye on Aceh and Aidwatch 2006).

This asymmetric power relation was reflected in the wider decision making process. During the peace negotiations between GAM and the government of Indonesia before the tsunami disaster happened, women were never involved. After the tsunami disaster, the participation of woman existed, but only in the late time. There was only one woman, Shadia Marhaban, who participated as the part of GAM delegation in the late period of the negotiation process held in Helsinki, Finland, eight months later after the tsunami disaster (Leo-Koo 2012). The negotiators from GAM were usually all men. This negotiation was finally able to end the conflict and produced the Helsinki Peace Agreement (2005), but there was no article that specifically talked about women or girls. Instead, it highlighted the implementation of Sharia Law in Aceh which worsened the violation of women's rights in that province through some of its bylaws (Gray et al. 2009, 5).

\subsection{The Intersectional Social Injustice of Tsunami 2004}


The recovery process has brought gendered dimensions more clearly as what have discussed above. However, the patterns emerged were not solely in terms of gender oppression. Tsunami 2004 mirrored the already-existing gendered social structures, identities, social class, and power dynamics. It then produced such an intersecting stratified context. The tsunami occurred as the climax to a long story of impoverishment and deterioration of natural resources and of the quality of life and living conditions of the population. The New Order regime set the economic model of development based on external needs and it promoted the exploitation of natural resources. During the 1980s, the State became the key actor in development, but military conflict, among other things, weakened this model. Strict stabilization and adjustment programs resulted in economic growth for a select few and increased poverty and inequality for the majority (Iis 2011).

Looking back on the history, the economic crisis of Indonesia and the civil war occurred for decades have resulted in the unstable economy of Acehnese. Unskilled labor, low wages, especially when women and children are hired, poor working conditions, and no social security system mean that the reproduction of the workforce become completely the responsibility of family units; particularly the women. Because of that, women tended to enter micro-businesses, in a form of self-employment. Children and adolescents work in the cities and in the countryside in a variety of economic activities: street sales, shoe shining, hauling, singing, day labor, seasonal work, agricultural work and high-risk activities on plantations, trucking, and in mines (Iis 2011, 970). A greater impoverishment of families in Aceh after tsunami means a larger share of the work burden carried by female adults, adolescents, and children. This implies the cutting of women's participation as citizens, as well as the relegation of priorities regarding their rights in terms of sexual and reproductive health. Furthermore, looking at the geographic shares of wealth, most resources and investments are still focused on urban areas and rural zones are marginalized. Privileged status and position in all aspects in public area are given to men over women. Certain ethnic groups have greater power and access to the process; whereas, adults enjoy better conditions than do children and adolescents (Iis 2011, 972).

The other study using population-representative longitudinal survey data on individuals and households from coastal areas of Aceh and North Sumatra Provinces provides scientific evidence on the process of displacement in the immediate aftermath of the tsunami. Damage from the tsunami took many forms, many of which were influenced displacement, injuries, the death of household members, loss of or damage to assets and housing, loss of social networks, and damage to community infrastructure. The total damages and loss in the region were Rp 41,4 trillion, which $78 \%$ were people assets. The impact of the earthquake-driven tsunami affected a big and huge damages of infrastructures, such as road, bridge, and communication line. In the most severely damaged areas, people moved predominantly to areas outside of their original community and over half moved to camps or other temporary settlements. Gray et al. (2009) found in their study that even in these areas many individuals remained in their original residence or community of origin and many were able to stay with friend and family in private homes. Those individuals drew on all of their resources and moved to a preferred destination or chose to remain in their home. The decision for mobility was influenced by asset ownership and other features of pre-tsunami livelihood strategies. Among persons displaced from damaged areas, the less educated and those with fewer resources are more likely to move to a camp or temporary settlement rather than a private home. There were also flows of emigration towards other countries, mainly Malaysia and Saudi Arabia and the Middle Eastern Countries.

\section{Conclusion: Tsunami Passed, Gender Inequality Remained}


The 2004 tsunami brought many changes in the lives of men and women in Aceh. As explained above, this catastrophe killed more women than men due to the existing gendered role and responsibility between men and women. Consequently, men outnumbered women in the evacuation camps. This consequence posed men and women in different situations and this paper identified four main gender-specific dimensions on the impact of the tsunami. These four dimensions were interlinked to each other and posed women in the more disadvantaged position in the society after the tsunami disaster.

Women survivors became more insecure and vulnerable due to the lack of proper and secure facilities in the evacuation camps. Women did not have any power to participate in the coordination meetings, so the facilities set up did not accommodate their special needs, particularly of the pregnant women. Consequently, many women faced a problem with their health, experienced sexual violence, and domestic violence.

The tsunami disaster also caused the feminization of poverty because more women lived in poverty after the tsunami disaster because they did not have the power to decide an equal sharing of inheritance of their deceased father's properties nor to own their deceased husband's properties. The widows also became poorer because her access to aid was limited compared to the widowers. Women with surviving husband were also more prone to personal poverty due to the gendered division of ownership. Poor women were also more likely to be trapped in poverty because they could only access the typical low-paying jobs that were usually attributed to women, or had to experienced sexual exploitation from men for their survival.

Both men and women also saw marriage as a coping mechanism to survive the tsunami disaster. This decision led to some changes in the traditional practice of marriage. It broke the rigid restriction on social class in the society but it maintained the gender stereotype between men and women. Women still focused on the care-taking roles and in the domestic space and had to sacrifice their freedom to secure their and their families' future life.

Lastly, the gendered division of space between men and women were reinforced after the tsunami disaster. Men have been always the main actor in this process, while women's participation remained marginalised with a slight change; from being completely excluded before the tsunami came to being insignificantly involved after the tsunami passed. This asymmetric power relation was further reflected in the peace negotiation process in Helsinki a few months later. There was only one female representative involved in the late meeting and there was no article talking about women in the peace agreement.

Based on these gender-specific dimensions, one could conclude that inequalities between men and women in Aceh were worsened after the tsunami disaster. Women and men were still attributed with the same identities and were still involved in the same stereotype role and responsibilities. In the end, women became more vulnerable and powerless, while men still had many privileges in Aceh. Nonetheless, the devastating effects of the tsunami were also experienced differently by those men and women depending on their socio-economic conditions before the catastrophe. To that effect what is needed are coordinated actions and cooperation from all levels of society in order to overcome the stratification that divides the people in the region for political, religious or other reasons. 


\section{REFERENCES}

\section{Books}

Ariyabandu, M. M. 2009. "Sex, Gender and Gender Relations in Disaster.” In Women, Gender and Disaster: Global Issues and Initiatives, edited by E. Enarson and P. F. D. Chakrabarti, 5-17. Thousand Oaks, CA: Sage Publications.

Collins, Patricia Hill. 2000. Black Feminist Thought: Knowledge, Consciousness, and the Politics of Empowerment. Second. New York: Routledge.

Eye on Aceh, and Aidwatch. 2006. A People's Agenda?: Post-Tsunami Aid in Aceh. Banda Aceh: Eye on Aceh in consultation with Aidwatch.

Gray, Clark, Elizabeth Frankenberg, Thomas Gillespie, Cecep Sumantri, and Duncan Thomas. 2009. "Population Displacement and Mobility in Sumatra after the Tsunami," no. August.

Harding, Sandra. 1986. The Science Question in Feminism. Ithaca: Cornell University Press.

Schaffer, Howard B. 2011. "Making Peace When Disaster Strikes: Sri Lanka, Aceh and the 2004 Tsunami."

Safrilsyah. 2012. "Non-Muslim Under the Regulation of Islamic Law in Aceh Province." In Annual International Conference on Islamic Studies (AICIS XII), edited by Nur Kholis and Imas Maesaroh, 544-53. Surabaya.

UNFPA, Oxfam Great Britain, and Women Studies Centre of Ar Ranirry State Institute for Islamic Studies. 2005. "Gender and Changes in Tsunami-Affected Villages in Nanggroe Aceh Darussalam Province," no. December.

\section{Journals}

Crenshaw, Kimberle. 1989. "Demarginalizing the Intersection of Race and Sex : A Black Feminist Critique of Antidiscrimination Doctrine, Feminist Theory and Antiracist Politics." University of Chicago Legal Forum 1989 (1): 139-67.

Felten-Biermann, C. 2006. "Gender and Natural Disaster: Sexualized Violence and the Tsunami." Development 49 (3): 82-86.

Iis, E M Yusuf. 2011. "The State of Aceh Before The Earthquake Driven Tsunami: Some Preliminary Research Notes.” Jurnal Asy-Syir'ah 45 (I): 961-78.

Leo-Koo, K. 2012. "Gender at the Crossroad of Conflict: Tsunami and Peace in Post-2005 Aceh." Feminist Review 101: 59-77.

Luft, Rachel E. 2016. "Racialized Disaster Patriarchy: An Intersectional Model for Understanding Disaster Ten Years after Hurricane Katrina." Feminist Formations 28 (2): $1-26$.

Muktakhamah, T. 2013. "Pentingnya Pengarusutamaan Gender Dalam Program Pengurangan Risiko Bencana.” Welfare Jurnal Ilmu Kesejahteraan Sosial 2 (1): 37-54.

Srimulyani, Eka. 2015. "Women and Matrimonial Lives in Aceh 'Matrifocal' Society: A Preliminary Survey.” Heritage of Nusantara 4 (2): 313-28.

\section{Internet}

“Aceh: Before the Tsunami." 2005, June 21. www.scoop.co.nz/stories/WO0506/S00323.htm. Bangka Pos. 2016. "9 Fakta Gempa Dan Tsunami Aceh Yang Menakutkan," December 8. http://bangka.tribunnews.com/2016/12/08/9-fakta-gempa-dan-tsunami-aceh-yangmenakutkan?page $=2$. 
The Government of the Republic of Indonesia, and The Free Aceh Movement. 2005. The Helsinki Peace Agreement. http://www.acehpeaceprocess.net/pdf/mou_final.pdf. UNDP. 2013. "Gender and Disaster Risk Reduction." United Nations Development Programme. http://www.undp.org/content/dam/undp/library/gender/Gender and Environment/PB3-AP-Gender-and-disaster-riskreduction.pdf\%0Awww.undp.org/gender. 